\begin{tabular}{|c|c|c|}
\hline 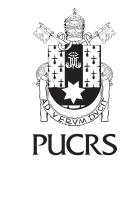 & $\begin{array}{l}\text { ESCOLA DE } \\
\text { HUMANIDADES }\end{array}$ & $\begin{array}{l}\text { Revista de Filosofia da PUCRS } \\
\text { Veritas, Porto Alegre, v. 65, n. 1, p. 1-16, jan.-mar. } 2020 \\
\text { e-ISSN: 1984-6746 | ISSN-L: 0042-3955 }\end{array}$ \\
\hline do) http & $/ / 10.15448 / 1984-6746.2020 .1 .36648$ & \\
\hline
\end{tabular}

SEÇÃO: VARIA

\title{
Linguagens da morte: revisitando a linguagem totalitária com Arendt e Klemperer
}

\author{
Death languages: revisiting totalitarian language with Arendt and Klemperer \\ Lenguajes de la muerte: revisitar el lenguaje totalitario con Arendt y Klemperer
}

Ricardo Timm de Souza ${ }^{1}$ orcid.org/0000-0002-9422-0420 timmsouz@pucrs.br

Recebido em: 12 dez. 2019. Aprovado em: 26 dez. 2019. Publicado em: 12 mai. 2020.
Resumo: O texto pretende, a partir de abordagens das obras Eichmann em Jerusalém - um relato sobre a banalidade do mal, de Hannah Arendt e de LTI - A linguagem do terceiro Reich, de Victor Klemperer, caracterizar algumas caracteristicas da linguagem nazista de relevância para a compreensão da contemporaneidade. especialmente no que tange à confecção dos chamados discursos de "pós-verdade". Palavras-chave: Linguagem totalitária. Discursos de "pós-verdade". Contemporaneidade. Sentido da linguagem.

Abstract: Based on approaches from Eichmann in Jerusalem - an account of the banality of evil, by Hannah Arendt and LTI - The language of the Third Reich, by Victor Klemperer, the text aims to characterize some features of Nazi language of relevance to understanding contemporaneity, especially with regard to the making of the so-called "post-truth" discourses.

Keywords: Totalitarian language. "Post-truth" discourses. Contemporaneity. Sense of language.

Resumen: El texto pretende, desde los acercamientos a las obras Eichmann en Jerusalén - un relato de la banalidad del mal, de Hannah Arendt y LTI - El lenguaje del tercer Reich, de Klemperer, explicitar algunas caracteristicas de la lengua nazi de relevancia para comprensión de la contemporaneidad, especialmente con respecto a la realización de los llamados discursos de "post-verdad". Palabras clave: Lenguaje totalitario. Discursos de "posverdad". Contemporaneidad. Sentido del lenguaje.

\section{Introdução}

Qual a atualidade das análises empreendidas há tantas décadas por $\mathrm{H}$. Arendt sobre a figura, o caráter e o discurso de Otto Adolf Eichmann e por V. Klemperer sobre a linguagem totalitária - no caso, nazista? O artigo procura demonstrar até que ponto tais análises possuem extrema atualidade na contemporaneidade assombrada por discursividades delirantes e que se apresentam como substitutos do pensamento em suas múltiplas expressões. É possivel que a temática da "pós-verdade" não seja tão nova assim como pensaram tantos intelectuais e pessoas atentas quando da escolha de "pós-verdade" como "termo do ano" em anos recentes. $O$ presente artigo pretende abordar essa questão e relevar a impressionante atualidade das análises de Arendt e Klemperer, a partir de uma visão filosófica que se debruça sobre suas respectivas hermenêuticas. 


\section{Arendt, Eichmann e seu discurso}

"O nazismo se embrenhou na carne e no sangue das massas por meio de palavras, expressões e frases impostas pela repetição, milhares de vezes, e aceitas inconsciente e mecanicamente".

(V. Klemperer $)^{2}$

"Senti que teria de viver uma vida individual dificil e sem liderança, não receberia diretivas de ninguém, nenhuma ordem, nem comando me seriam mais dados, não haveria mais nenhum regulamento pertinen-

te para consultar - em resumo, havia diante de mim uma vida desconhecida".

(A. Eichmann) 3

"A formação do caráter é uma questão nitidamente menor: dominar o corpo é mais importante do que receber educação".

(V. Klemperer $)^{4}$

Ocorre uma correlação direta entre a atrofia da linguagem como potência vital nomeadora da realidade, ou seja, como verbo dos acontecimentos ou realidade verbalizada para além da pretensão de onipotência totalizante do Eu - o esvaziamento de responsabilidade de sentido que um tal movimento necessariamente significa - e a instalação, no vazio criado por essa ausência povoada pelo estático, de um crescente potencial idolátrico.

A famosa crônica de Hannah Arendt sobre o julgamento de Otto Adolf Eichmann ${ }^{5}$ é extremamente rica, seja na própria interpretação de Arendt, seja na letra dos depoimentos de Eichmann, em termos de exemplificação cabal do resultado final de um tal esvaziamento de peso de realidade, ou seja, de sentido propriamente de linguagem, da linguagem.

A pontuação inicial de uma postulação de linguagem em termos verticais, não significativa à comunicação, mas à denominação ao molde de etiquetagens em um universo estático de acontecimentos novos, ou seja, nos quais os acontecimentos se adaptam a estruturas prévias especialmente em termos de ordenações hierárquicas, é característica de todos os depoimentos de Eichmann, como Arendt bem destaca. Já de início, o que se tem é uma entidade metafísica absoluta, o "mais alto portador de sentido" ("Höher Sinnesträger") a partir da qual tudo o demais é medido em termos de caracterizações e ações. Eichmann era um "crente de Deus" ou "crente em Deus" ("Gottgläubiger") que abjurara o cristianismo. O que, à primeira vista, parece um movimento de iconoclastia ou a expressão de uma vontade consciente, logo após deixa transparecer sentidos mais evidentes e menos complexos, no sentido da "verticalização" atrás referida:

Segundo suas crenças religiosas, que não haviam mudado desde o período nazista (em Jerusalém, Eichmann declarou-se um Gottgläubiger, termo nazista usado para aqueles que haviam rompido com o cristianismo, e recusou-se a jurar sobre a Bíblia), esse acontecimento (os temas em pauta, R. T. S.) devia ser atribuido a um "Portador de sentido superior, uma entidade de certa forma identificada com o "movimento do universo", à qual a raça humana, em si isenta de "sentido superior", deveria estar sujeita. (A terminologia é bastante sugestiva. Chamar Deus de Höher Sinnesträger significa, linguisticamente, dar a ele um posto na hierarquia militar, uma vez que os nazistas haviam transformado o "recebedor de ordens", o Befehlsträger, num "portador de ordens", um Befelsträger, indicando assim, como no antigo termo "portador de más noticias", a carga de responsabilidade e de importância que devia pesar sobre aqueles que executavam ordens. Além disso, Eichmann, como todo mundo ligado à Solução Final, também era oficialmente um "portador de segredos", um Geheimnisträger, coisa que em termos de vaidade não era de se desprezar) (grifo nosso). ${ }^{6}$

A estruturação de uma hierarquia de realidade que aproxima uma cosmologia particular do universo mais prosaico da lógica militar não é sem consequências. O que se pode observar aqui é o afunilamento do sentido de realidade da realidade no ponto de união entre uma entidade metafísica máxima, o Höher Sinnesträger, e o ponto lógico

2 KLEMPERER, V., LTI - A linguagem do terceiro Reich, Rio de Janeiro: Contraponto, 2009, p. 55.

Otto Adolf Eichmann, apud ARENDT, H., Eichmann em Jerusalém - um relato sobre a banalidade do mal, São Paulo: Cia. das Letras, 1999, p. 43-44.

KLEMPERER, V., 2009, p. 40. "Pensar é uma forma de castração. por isso, a cultura é suspeita na medida em que é identificada com atitudes críticas". ECO, U., O fascismo eterno. Rio de Janeiro: Record, 2018, p. 48.

5 ARENDT, H., 1999.

6 ARENDT, H., 1999, p. 38-39. 
absoluto do qual deriva toda a atividade vital, em uma dimensão, como apontamos, perfeitamente verticalizada. Não há espaço para movimento, nem tempo para acontecimentos novos ou inesperados; a vida se resume, finalmente, no receber e passar adiante o que chega desde o absoluto, em uma espécie de paradoxal movimentação estática.

O que, agora, contrasta retintamente com uma tal "ordem pré-ordenada" e assumida é a forma como Eichmann integrou-se ao partido Nazista. Não uma expressão de vontade, não uma revelação superior, mas uma precipitação involuntária de acontecimentos incontroláveis que desembocou nessa antítese improvável: de alguém a quem o partido Nazista era inicialmente "completamente indiferente" a alguém que se tornou uma de suas expressões práticas mais notórias e destacadas pelas funções que ocupou e exerceu, na lógica de seus superiores, a pleno contento:

De toda forma, não entrou para o Partido por convicção nem jamais se deixou convencer por ele - sempre que the pediam para dar razões, repetia os mesmos clichês envergonhados sobre o Tratado de Versalhes e o desemprego: antes, conforme declarou no tribunal, "foi como ser engolido pelo Partido contra todas as expectativas e sem decisão prévia. Aconteceu muito depressa e repentinamente". Ele não tinha tempo, e muito menos vontade de se informar adequadamente, jamais conheceu o programa do Partido, nunca leu Mein Kampf. Kaltenbrunner disse para ele: Por que não se filia à SS? E ele respondeu: Por que não? Foi assim que aconteceu. e isso parecia ser tudo?

Mais uma vez, a questão presta-se a uma interpretação muito significativa. O que se expressa nesse episódio é, na verdade, menos estranho do que parece. Eichmann está confessando, desde o início, que o pensamento sempre the foi alheio ${ }^{8}$. Desde o início, fica claro que suas escolhas não foram suas, mas daquilo que ele chamou de História ou Movimento. Ele se confessa um joguete nas mãos do destino, que assumiu tarefas pelas quais não tinha apreço por uma necessidade externa que não the deixava nenhuma outra hipótese de ação.

Evidentemente, isso não era tudo. O que Eichmann deixou de dizer ao juiz presidente durante seu interrogatório foi que ele havia sido um jovem ambicioso que não aguentava mais o emprego de vendedor viajante antes mesmo de a companhia de Óleo a Vácuo não o aguentar mais. De uma vida rotineira, sem significado ou conseqüência, o vento o tinha soprado para a História. pelo que ele entendia, ou seja, para dentro de um Movimento sempre em marcha e no qual alguém como ele - já fracassado aos olhos de sua classe social, de sua família e, portanto, aos seus próprios olhos também - podia começar de novo e ainda construir uma carreira. ${ }^{9}$

A ideia, o Movimento, a própria História o engolfaram sem lhe deixar escolha alguma. Havia, porém, uma característica prévia que o constituiu tão incapaz de tomar atitudes mais complexas: Arendt: "[...] uma falha mais específica, e também mais decisiva, no caráter de Eichmann era sua quase total incapacidade de olhar qualquer coisa do ponto de vista do outro". ${ }^{10}$ Seu mundo se reduzia à pobreza extrema de percepção, isolado em um mundo como que autorreferido, que o fez um tão bom funcionário do sistema. Incapaz de imaginar. vivia em um mundo mágico, na exata definição de idolatria de Flusser. Esse mundo mágico não permite criação, já que tudo se encontra desde sempre já criado para si mesmo. Pois a magia, considerada aqui em sua significação rudimentar e encantatória, nada cria, a não ser ilusões.

A próxima evidência é a de que a visibilidade de uma tal redução da realidade à magia se

\footnotetext{
7 Ibid., p. 44-45

8 Ao longo de toda obra, Arendt irá apontar e destacar esse fato; tais apontamentos são em tal número que não podem ser citados detalhadamente no presente contexto.

$9 \quad$ Ibid., p. 45. Segue Arendt: "E se ele nem sempre gostava do que tinha de fazer (por exemplo, despachar multidões que iam de trem para a morte em vez de força-las a emigrar), se ele não adivinhou antes que a coisa toda iria acabar mal, com a Alemanha perdendo a guerra, se todos os seus planos mais caros deram em nada (a evacuação dos judeus europeus para Madagascar, o estabelecimento de um território judeu na região Nisko, na Polônia, o experimento com instalações de defesa cuidadosamente construídas em torno de seu escritório de Berlim para repelir os tanques russos), e se, para sua grande "tristeza e sofrimento", ele nunca passou do grau de Obersturmbannführer da SS (posto equivalente ao de tenente-coronel) - em resumo, se, com exceção do ano que passou em Viena, sua vida fora marcada por frustações, ele jamais esqueceu qual seria a alternativa.".

10 Ibid., p. 60
} 
expressa perfeitamente no estreitamento da linguagem, até que esta se constitua em uma espécie de prisioneira de si mesma em seus elementos mais toscos e vulgares. Um universo extremamente restrito de significações acaba por se autoaprisionar em um invólucro préconstituido, sem possibilidade de alternativa ou escapatória. O não pensamento, a incapacidade de conceber perspectivas diferentes no que se relaciona a uma posição fixa em um dado mundo no qual todo sentido se esgota no estático, acaba por determinar o aprisionamento das ideias em fórmulas derivadas da semântica mais rasa ou mais obliterada, no sentido etimológico da palavra idiota - da língua como expressão de linguagem, que culmina na expressão clichê:

O texto alemão do interrogatório policial gravado, realizado de 29 de maio de 1960 a 17 de janeiro de 1961 [...], constitui uma verdadeira mina de ouro para um psicólogo - contanto que ele tenha a sabedoria de entender que o horrivel pode ser não só ridiculo como rematadamente engraçado. Parte do humor não pode ser transmitido em outra lingua, porque está justamente na luta heroica que Eichmann trava com a língua alemã, que invariavelmente o derrota. É engraçado quando ele usa o termo "palavras aladas" (geflügelte Worte, um coloquialismo alemão para designar citações famosas dos clássicos) querendo dizer frases feitas, Redensarten. ou slogans, Schlagworte. Era engraçado quando, durante a inquirição sobre os documentos Sassen, feita em alemão pelo juiz presidente, ele usou a frase "kontra geben" (pagar na mesma moeda), para indicar que havia resistido aos esforços de Sassen para melhorar suas histórias; o juiz Landau, desconhecendo evidentemente os mistérios dos jogos de cartas (de onde provém a expressão), não entendeu, e Eichmann não conseguiu achar nenhuma outra maneira de se expressar. Vagamente consciente de uma incapacidade que deve tê-lo perseguido ainda na escola [...] ele pediu desculpas, dizendo: "Minha única língua é o oficialês [Amtssprache]". Mas a questão é que o oficialês se transformou em sua única lingua porque ele sempre foi genuinamente incapaz de pronunciar uma única frase que não fosse um clichê. ${ }^{11}$

A linguagem se empedra. Esse é o indício de sua morte próxima, quando tudo o que sobrar serão gritos e murmúrios inarticulados, repetição espasmódica de fórmulas, clichês revestidos de tonalidades impróprias e com ridicula pretensão de aparecerem como verdades definitivas. A linguagem petrificada é incapaz de reconhecer o desvanecimento do seu tempo interno, evadido com sua vida própria, ou seja, com sua verbalidade, sem a qual ela não se constitui em nada senão em eco mecânico do tilintar de coisas que se chocam umas com as outras. De fato, ocorre algo como uma mecanização, uma maquinização extrema do discurso, que se torna em ferramenta utilizável em contextos nos quais se esperaria mais do que um mero monólogo idiotizado ${ }^{12}$.

Arendt bem observa que nada como palavrório mecânico que retorna a si mesmo - eterno retorno do Mesmo - para proteger do poder desagregador de que dispõe uma única palavra verdadeira, ou seja, estribada no além do círculo mágico constituído pelo idiota para sua proteção contra o perigo da vida. No palavrório não subsiste uma única palavra real, pois tudo se transformou em fórmula circular que reenvia constantemente para o adiamento de um possivel sentido, pois é do sentido que o palavrório pretende precisamente

\footnotetext{
11 Ibid., p. 61. Segue Arendt: "(Será que foram clichês que os psiquiatras acharam tão "normais" e "desejáveis"? Serão essas as "ideias positivas" que um clérigo espera encontrar nas almas para as quais ministra? A melhor oportunidade para Eichmann demonstrar esse lado positivo de seu caráter em Jerusalém surgiu quando o jovem oficial de polícia encarregado de seu bem-estar mental e psicológico deu-lhe um exemplar de Lolita para relaxar. Dois dias mais tarde, Eichmann devolveu o livro, visivelmente indignado; "Um livro nada saudável" - "Das ist aber ein sehr unerfreuliches Buch" - disse ele a seu guarda)"

12 Conforme M. Horkheimer: "Quanto mais ideias se tornam automáticas, instrumentalizadas, menos alguém vê nelas pensamentos com um significado próprio São consideradas como coisas, máquinas. A linguagem tornou-se apenas mais um instrumento no gigantesco aparelho de produção da sociedade moderna. Qualquer sentença que não seja equivalente a uma operação nesse aparelho parece a um leigo tão sem sentido como pareceria aos semanticistas contemporâneos, os quais sugerem que a sentença puramente simbólica e operacional, isto é, a sentença puramente sem sentido, faz sentido. O significado é suplantado pela função ou efeito no mundo das coisas e eventos. Desde que as palavras não sejam usadas de modo evidente para calcular tecnicamente probabilidades adequadas ou para outros propósitos práticos, entre os quais se inclui o recreio e a distração, arriscam-se a serem suspeitas de alguma espécie de interesse comercial, pois a verdade não é um fim por si mesmo". HORKHEIMER, M., Eclipse da razão, São Paulo: Centauro, 2002, p. 27. Horkheimer é preciso em apontar a correlação intima entre a instrumentalização das ideias e aquela da linguagem, não apenas em nivel qualitativo, mas também em termos quantitativos; e isso não constitui um apanágio do nazismo ou mesmo do fascismo, mas se desdobra em inúmeros estilos de positivismo que hoje dominam boa parte das ciências.
} 
escapar. A asserção do absoluto, condensada no epicentro do palavrório, interdita absolutamente a comunicação em todos os seus sentidos; não se trata de um vazio a ser preenchido, mas de uma repleção que ocupa todos os espaços e tempos, o proferir monumentalizado ${ }^{13}$, aquilo que pretende se constituir em uma espécie de centro tantalizante de um círculo autorrefletido: ausência de linguagem pela presença excessiva de seus símiles. A língua etimologicamente bem denominada idiota não pretende nada senão ser si mesma, por isso desconcerta, em uma primeira aproximação, qualquer expectativa de diálogo, ou mesmo de monólogo do qual algum significado mais ou menos oculto possa ser haurido:

Sem dúvida, os juizes tinham razão quando disseram ao acusado que tudo o que dissera era "conversa vazia" - só que eles pensaram que o vazio era fingido, e que o acusado queria encobrir outros pensamentos que, embora hediondos, não seriam vazios. Essa idéia parece ter sido refutada pela incrivel coerência com que Eichmann, apesar de sua má memória, repetia palavra por palavra as mesmas frases feitas e clichês semi-inventados (quando conseguia fazer uma frase própria, ele a repetia até transformá-la em clichê) toda vez que se referia a um incidente ou acontecimento que achava importante. Quer estivesse escrevendo suas memórias na Argentina ou em Jerusalém. quer falando com o interrogador policial ou com a corte, o que ele dizia era sempre a mesma coisa, expressa com as mesmas palavras. Quanto mais se ouvia Eichmann, mais óbvio ficava que sua incapacidade de falar estava intimamente relacionada com sua incapacidade de pensar, ou seja, de pensar do ponto de vista de outra pessoa. Não era possivel nenhuma comunicação com ele, não porque mentia, mas porque se cercava do mais confiável de todos os guarda-costas contra as palavras e a presença de outros, e, portanto, contra a realidade enquanto tal. ${ }^{14}$
Arendt é precisa, igualmente, no próximo passo, aquele que aproxima até a identificação entre incapacidade de falar e incapacidade de pensar. O círculo idiótico, ao estabelecer uma muralha suficientemente densa em defesa contra a possibilidade de penetração da realidade enquanto tal, significa nitidamente o horror ao pensamento, ou seja, a alguma forma de testemunho de contato com o externo; a realidade postiça da autorreferência ocupa todos os espaços possiveis de permuta e mesmo de percepção relativamente ao externo a ela; poderiamos evocar aqui a ideia de um delírio paranoico lato senso que habita não um indivíduo ou um psiquismo "particular", mas uma atmosfera de existência que se substitui a uma sociedade propriamente pensante e ativa na consciência de sua origem e perduração, em uma espécie de onirismo paralisado ${ }^{15}$.

Ao empedramento da linguagem, acompanha o empedramento da memória. Nada tem sentido memorável, a não ser aquilo que possa pretensamente fazer "sentido" (i. e., reforçar a carapaça isolante) à autorreferência idiótica. Isso não é coincidência; o contato com a realidade inclui necessariamente a deriva de elementos restantes, rastros, traços do que aconteceu, do que foi considerado significativo e não significativo; a exacerbação de uma espécie de esquecimento mecânico é, portanto, necessária para desativar o poder potencialmente desagregador desses rastros e traços.

Sua memória resultou bem pouco confiável a respeito do que realmente aconteceu; num raro momento de exasperação, o juiz Landau perguntou ao acusado: "O que você consegue lembrar?" (se não se lembrava das discussões na chamada Conferência de Wannsee, que debateu os vários métodos de morte), e a resposta, claro, foi que Eichmann se lembrava bastante bem dos momentos decisivos de sua carreira, mas isso não coincidia,

13 Cf. SOUZA, R. T., Kafka, a justiça, o Veredicto e a Colônia Penal, São Paulo: Perspectiva, 2012.

14 ARENDT, H., 1999, p. 61-62. (grifo nosso, R. T. S.)

15 "A estonteante disposição de Eichmann, primeiro na Argentina, depois também em Jerusalém, a admitir seus crimes devia-se menos a sua capacidade criminosa de autoengano do que à aura de sistemática hipocrisia que constituía a atmosfera geral, aceita por todos, do Terceiro Reich. "Claro" que ele havia desempenhado um papel no extermínio dos judeus; "claro" que se "não os tivesse transportado, eles não teriam sido entregues aos açougueiros." "O que existe aí para admitir?", ele perguntava. Agora, continuava, "gostaria de fazer as pazes com [seus] antigos inimigos" - sentimento que partilhava não só com Himmler, que o expressou durante o último ano da guerra, e também com o líder das frentes de trabalhos forçados, Robert Ley (que, antes de se suicidar em Nuremberg, havia proposto o estabelecimento de um "comitê de conciliação" formado pelos nazistas responsáveis pelos massacres e por sobreviventes judeus), e que partilhava também, inacreditavelmente, com muitos alemães comuns, que sabidamente se expressaram exatamente nos mesmos termos no final da guerra." Ibid., p. 65-66. 
necessariamente, com os momentos decisivos da história do extermínio dos judeus ou, na verdade, com os momentos decisivos da história. (Ele sempre teve dificuldades para se lembrar da data exata do começo da guerra e da invasão da Rússia.) Mas o xis da questão é que ele não esqueceu nem uma única frase daquelas que em algum momento the deram uma "sensação de ânimo".16

"Apesar de todos os esforços da promotoria, todo mundo percebia que esse homem não era um 'monstro', mas era dificil não desconfiar que fosse um palhaço. ${ }^{17}$ A realidade é que, à corte ali reunida em tão grave empreendimento - julgar um dos maiores genocidas da II Guerra mundial -, os problemas de interpretação da figura ali postada e daquilo que nele se apresentava como linguagem eram complexose desafiadores, muito mais do que se poderia esperar inclusive na lida com um impostor esperto. Onde juiz, promotores e defensores procuravam dissimulação e artimanhas diversionista, encontravam apenas uma parede aparentemente impenetrável e não dissimulada. ${ }^{18}$ Entre essas dificuldades, uma especialmente se destaca na linguagem idiótica (e, destaquemos desde já, por óbvio, não apenas nesse famoso caso Eichmann, mas em inúmeras outras circunstâncias, por vezes aparentemente completamente afastadas de uma tal situaçãolimite): a naturalidade espantosa com a qual lida com contradições primárias como se essas não existissem, ou não significassem o que expressam, ou seja, mútua exclusão de sentido. Trata-se, para um raciocínio primário, inferencial, ou que meramente se inspira na ideia coloquial de causa e efeito, de uma ofensa escancarada, expressa com uma naturalidade desconcertante e que fecha qualquer acesso a um diálogo com algum sentido. Ao que parece, trata-se de um subproduto da degeneração do tempo real em um tempo meramente lógico, constituído de peças soltas continuamente rearranjáveis de acordo com a arbitrariedade que sustenta o construto da linguagem idiótica. Em todo caso, aparece aos interlocutores como uma eterna novidade a cada vez que aparece, desencorajando qualquer esperança de avanço na interação que se procura estabelecer:

O que fazer com um homem que primeiro declarou com grande ênfase que a única coisa que aprendeu numa vida desperdiçada foi jamais fazer um juramento ("Hoje em dia, nenhum homem. nenhum juiz poderia me convencer a fazer uma declaração sob juramento. a declarar alguma coisa sob juramento como testemunha. Eu recuso, eu recuso por razões morais. Como minha experiência me diz que, ao ser leal a seu juramento, o sujeito um dia terá de pagar as consequências, decidi definitivamente que nenhum juiz no mundo, nem nenhuma outra autoridade nunca será capaz de me fazer jurar, ou prestar testemunho sob juramento. Não farei uma coisa dessas voluntariamente e ninguém conseguirá me forçar"), e então. depois de ser informado explicitamente que, se quisesse testemunhar em sua própria defesa, poderia "fazê-lo com ou sem juramento", declarou sem mais delongas que preferiria testemunhar sob juramento? Ou como alguém que garantiu à corte [...], que a pior coisa que ele poderia fazer seria tentar escapar de suas verdadeiras responsabilidades para lutar por seu pescoço ou implorar misericórdia - e depois, aconselhado por seu advogado, apresentou um documento escrito à mão com um pedido de misericórdia? ${ }^{19}$

Esse jogo de contrários inconciliáveis constantemente postos em cena é característico

\footnotetext{
16 Ibid., p. 66. Segue Arendt: "E ficavam ultrajados e desconcertados quando descobriam que o acusado tinha a sua disposição um clichê de ânimo diferente para cada periodo de sua vida e cada uma de suas atividades. Na cabeça dele, não havia contradição entre "Vou dançar no meu túmulo, rindo" adequado para o fim da guerra, e "Posso ser enforcado em público como exemplo para todos os antissemitas da Terra", que agora, em circunstâncias muito diferentes, preenchia exatamente a mesma função de lhe dar um empurrão."). $17 \quad$ Ibid., p. 67.

18 "Esses hábitos de Eichmann criaram consideráveis dificuldades durante o julgamento - menos para Eichmann do que para aqueles que ali estavam para acusá-lo, defendê-lo, julgá-lo e descrevê-lo. Por tudo isso, era essencial que ele fosse levado a sério, o que era muito dificil, a menos que se procurasse a saida mais fácil para o dilema entre o horror inenarrável dos atos e o inegável absurdo do homem que os perpetrara, isto é, a menos que se declarasse um mentiroso esperto, calculista - coisa que evidentemente não era". ARENDT, 1999, p. 66. Segue Arendt: "Suas próprias convicções sobre isso estavam longe de ser modestas: "Um dos poucos dons com que o destino me abençoou é a capacidade para a verdade, na medida em que ela depende de mim". Esse dom ele reclamava para si mesmo antes de o promotor pretender lhe atribuir crimes que não havia cometido. Nas anotações desorganizadas e confusas que fez na Argentina, preparando-se para a entrevista com Sassen, quando ainda estava, como ele mesmo chegou a dizer na época, "em plena posse de sua liberdade física e psicológica", ele lançou um fantástico alerta para que os "historiadores futuros sejam objetivos a ponto de não se desviar da trilha da verdade aqui gravada" - fantástico porque cada linha dessas anotações revela sua total ignorância de tudo que não fosse direta, técnica e burocraticamente ligado a seu trabalho, sem falar de sua memória extraordinariamente deficiente." Ibid., p. 66-67. 19 ARENDT, 1999, p. 67-68.
} 
da atrofia do sentido de linguagem da linguagem. Como nada tem peso, tudo é intercambiável. Os termos e categorias da compreensão não valem mais a partir de suas distinções qualitativas originais, mas somente em termos de ocuparem um determinado espaço na dimensão mais elementar de algo que se poderia considerar - remotamente - uma paródia da ideia de comunicação. A fragmentação da organicidade do complexo significante é sem retorno, o que faz com tais episódios enunciativos, opostos e contraditórios entre si, avessos a toda lógica de exclusão e a toda dialética possível, apareçam como testemunhos eloquentes de tal fragmentação. Por isso, aparentam ser suportáveis no que se apresenta como sendo expressão de linguagem e que, todavia, expressa apenas a dissolução da qualidade da linguagem que faz valer cada uma de suas diferenças constitutivas em uma coleção de quantidades na qual, como dissemos, cada parte é completamente isolada de cada outra, cada fragmento sobrevive isoladamente em desconexão completa com um espectro maior de sentido e cujo prazo de validade coincide com a duração da pretensão de enunciado, algo breve demais para poder ser tomado a sério. A lógica reificante da quantificação ilimitada do mundo assume aqui sua expressão incontornável; essa paródia da linguagem configurada a partir de fragmentos mutuamente excludentes de ideia lançadas ao ar reflete, com fidelidade, um mundo configurado por átomos a rigor completamente isolados um do outro e aparentemente independentes entre si. As mônadas esvoaçantes não configuram uma complexidade coesa para que se perceba uma verdadeira relação para além do solipsismo do enunciado, que emula em proporção menor a atomização do real em "indivíduos" indivisiveis - cuja autorreferência é infinitamente mais importante do que qualquer relação real no campo histórico ou social. A linguagem é extremamente pobre porque a ideia de vida que a ela subjaz assim o é; a atrofia da linguagem não é um infeliz acidente, mas a consequência necessária da atrofia do mundo. Um mundo que se inclina à morte pelo esgotamento, pela impossibilidade de comunicação, da própria ideia de comunicação. Tal configuração de coisas não poderia desembocar senão em um universo cadavérico, pelo triunfo antecipado da morte. que se expressa pela "obediência cadavérica":

Era assim que as coisas eram, essa era a nova lei da terra, baseada nas ordens do Führer; tanto quanto podia ver, seus atos eram os de um cidadão respeitador das leis. Ele cumpria o seu dever, como repetiu insistentemente à polícia e à corte; ele não só obedecia a ordens, ele também obedecia à lei. Eichmann tinha uma vaga noção de que isso podia ser uma importante distinção. mas nem a defesa nem os juizes jamais insistiram com ele sobre isso. As moedas bem gastas das "ordens superiores" versus os "atos do Estado" circulavam livremente; haviam dominado toda a discussão desses assuntos durante os julgamentos de Nuremberg, pura e simplesmente por dar a ilusão de que algo absolutamente sem precedentes podia ser julgado de acordo com precedentes e seus padrões. Eichmann, com seus dotes mentais bastante modestos, era certamente o último homem na sala de quem se podia esperar que viesse a desafiar essas idéias e agir por conta própria. Como além de cumprir aquilo que ele concebia como deveres de um cidadão respeitador das leis, ele também agia sob ordens - sempre o cuidado de estar "coberto" -, ele acabou completamente confuso e terminou frisando alternativamente as virtudes e os vícios da obediência cega, ou a "obediência cadavérica" (kadavergehorsam), como ele próprio a chamou. ${ }^{20}$

À "obediência cadavérica" segue-se a filiação a Kant e ao seu imperativo categórico:

A primeira indicação de que Eichmann tinha uma vaga noção de que havia mais coisas envolvidas nessa história toda do que a questão do soldado que sempre cumpre ordens claramente criminosas em natureza e intenção apareceu no interrogatório da polícia, quando ele declarou, de repente, com grande ênfase, que tinha vivido toda a sua vida de acordo com os princípios morais de Kant, e particularmente segundo a definição kantiana do dever. Isso era aparentemente ultrajante, e também incompreensivel, uma vez que a filosofia 
moral de Kant está intimamente ligada à faculdade de juizo do homem, o que elimina a obediência cega. O oficial interrogador não forçou esse ponto, mas o juiz Raveh, fosse por curiosidade, fosse por indignação pelo fato de Eichmann ter a ousadia de invocar o nome de Kant em relação a seus crimes, resolveu interrogar o acusado. E para surpresa de todos, Eichmann deu uma definição quase correta do imperativo categórico: "O que eu quis dizer com minha menção a Kant foi que o princípio de minha vontade deve ser sempre tal que possa se transformar no princípio de leis gerais" (o que não é o caso com roubo e assassinato, por exemplo, porque não é concebivel que o ladrão e o assassino desejem viver num sistema legal que dê a outros o direito de roubá-los ou matá-los). Depois de mais perguntas, acrescentou que lera a Crítica da razão pura, de Kant. E explicou que, a partir do em que fora encarregado de efetivar a Solução Final, deixara de viver segundo os principios kantianos, que sabia disso e que se consolava com a idéia de que não era mais "senhor de seus próprios atos", de que era incapaz de "mudar qualquer coisa". ${ }^{21}$

O ponto de chegada é, sempre, o estático absoluto. "A culpa é sempre indubitável", diz o oficial ao explorado em A colônia penal, de Kafka²2.
O sequestro pelo absoluto esgota imediatamente qualquer sentimento ou expressão possivel de autonomia; ocorre a mais completa robotização do sequestrado: mesmo um kantiano convicto tem agora outro senhor, ao qual não cumpre questionar, mas obedecer, pois nele repousa a própria realidade do subordinado, que é, também, seu admirador mais extremo ${ }^{23}$. Nesse momento, aparece com plena clareza o mecanismo redutivo fático que acompanha o afunilamento atrofiante das possibilidades de linguagem e de expressão em geral. Arendt destaca bem esse outro aspecto decisivo desse fenômeno que temos chamado "sequestro pelo absoluto". O foco aqui é na onipresença e na onipotência absolutas da Lei.

Em Jerusalém, confrontado com provas documentais de sua extraordinária lealdade a Hitler e à ordem do Führer. Eichmann tentou muitas vezes explicar que durante o Terceiro Reich "as palavras do Führer tinham força de lei" (Führerworte haben Gesetzkraft), o que significava, entre outras coisas, que uma ordem vinda diretamente de Hitler não precisava ser escrita. Ele tentou explicar que, por isso, nunca havia pedido uma ordem escrita a Hitler (nenhum documento relativo à Solução Final jamais

${ }_{21}$ ARENDT, 1999, p. 153. Segue Arendt: "O que não referiu à corte foi que "nesse período de crime legalizado pelo Estado", como ele mesmo disse, descartara a fórmula kantiana como algo não mais aplicável. Ele distorcera seu teor para: aja como se o princípio de suas ações fosse o mesmo do legislador ou da legislação local - ou, na formulação de Hans Frank para o "imperativo categórico do Terceiro Reich", que Eichmann deve ter conhecido: "Aja de tal modo que o Führer, se souber de sua atitude, a aprove" (Die Technik des Staates, 1942, p.15-6) Kant, sem dúvida, jamais pretendeu dizer nada desse tipo; ao contrário, para ele todo homem é um legislador no momento em que começa a agir: usando essa "razão prática" o homem encontra os princípios que poderiam e deveriam ser os principais da lei. Mas é verdade que a distorção inconsciente de Eichmann está de acordo com aquilo que ele próprio chamou de versão de Kant "para uso doméstico do homem comum". No uso doméstico, tudo o que resta do espírito de Kant é a exigência de que o homem faça mais que obedecer à lei, que vá além do mero chamado da obediência e identifique sua própria vontade com o princípio que está por trás da lei - a fonte de onde brotou a lei. Na filosofia de Kant, essa fonte é a razão prática; no uso doméstico que Eichmann faz dele, seria a vontade do Führer". Ibid, p. 153-154.

22 KAFKA, F., O Veredicto/Na Colônia Penal, São Paulo: Companhia das Letras, 1998, p. 38-39: "As coisas se passam da seguinte maneira. Fui nomeado juiz aqui na colônia penal. Apesar da minha juventude. Pois em todas as questões penais estive lado a lado com o comandante e sou também o que melhor conhece o aparelho. O principio segundo o qual tomo decisões é: a culpa é sempre indubitável. Outros tribunais podem não seguir esse principio, pois são compostos por muitas cabeças e além disso se subordinam a tribunais mais altos. Aqui não acontece isso, ou pelo menos não acontecia com o antigo comandante. O novo, entretanto, já mostrou vontade de se intrometer no meu tribunal, mas até agora consegui rechaçá-lo - e vou continuar conseguindo. O senhor queria que eu lhe esclarecesse este caso; é tão simples como todos os outros. Hoje de manhã um capitão apresentou a denúncia de que este homem, que foi designado seu ordenança e dorme diante da sua porta, dormiu durante o serviço. Na realidade ele tem o dever de se levantar a cada hora que soa e bater continência diante da porta do capitão. Dever sem dúvida nada difícil, mas necessário, pois ele precisa ficar desperto tanto para vigiar como para servir. Na noite de ontem o capitão quis verificar se o ordenança cumpria o seu dever. Abriu a porta às duas horas e o encontrou dormindo todo encolhido. Pegou o chicote de montaria e vergastou-o no rosto. Ao invés de se levantar e pedir perdão, o homem agarrou o superior pelas pernas, sacudiu-o e disse: "Atire fora o chicote ou eu o engulo vivo!". São estes os fatos. Faz uma hora o capitão se dirigiu a mim, tomei nota das declarações e em seguida lavrei a sentença. Depois determinei que pusessem o homem na corrente. Tudo isso foi muito simples. Se eu tivesse primeiro intimado e depois interrogado o homem, só teria surgido confusão. Ele teria mentido, e se eu o tivesse desmentido, teria substituido essas mentiras por outras e assim por diante. Mas agora eu o agarrei e não o largo mais. Está tudo esclarecido?".

${ }_{23}$ "Mas o elemento pessoal indubitavelmente envolvido não era fanatismo, era a sua genuina, "ilimitada e imoderada admiração por Hitler" (como disse uma das testemunhas da defesa) - por um homem que tinha conseguido subir de "cabo dos lanceiros a chanceler do Reich". Seria perda de tempo tentar entender o que era mais forte nele, sua admiração por Hitler ou sua determinação em continuar sendo um cidadão respeitador das leis do Terceiro Reich num momento em que a Alemanha já estava em ruinas. Ambos os motivos entraram em jogo uma vez mais durante os últimos dias da guerra, quando ele estava em Berlim e viu com violenta indignação como todo mundo a sua volta estava muito razoavelmente se arranjando com documentos falsos antes da chegada dos russos ou dos norte-americanos. Poucas semanas depois, Eichmann também começou a viajar com nome falso, mas então Hitler já estava morto, a 'lei local' não existia mais e ele, conforme disse, não estava mais preso a seu juramento. Pois o juramento feito pelos membros da SS era diferente do juramento militar dos soldados, na medida em que os ligava a Hitler e não à Alemanha" ARENDT, 1999, p. 166. 
foi encontrado; provavelmente nunca existiu nenhum), mas havia pedido para ver uma ordem escrita de Himmler. Sem dúvida era um estado de coisas fantástico, e bibliotecas inteiras de comentários jurídicos "abalizados" foram escritas demonstrando que as palavras do Führer, seus pronunciamentos orais, eram a lei do mundo. Dentro desse panorama "legal", toda ordem contrária em letra ou espírito à palavra falada por Hitler era, por definição, ilegal. ${ }^{24}$

\section{"Führerworte haben Gesetzkraft" - a} característica aglutinadora da língua alemã acaba por colaborar, aqui, com o assumir de uma cegueira ainda mais profunda. "Palavras do Führer" tornam-se uma só - "Führerworte" - e essas assumem a condição de "força de lei", de lei absoluta, no sentido de anterior à linguagem, à ponderação, à descrição ou à hermenêutica de algum sentido que não refulja no próprio jargão como uma revelação imediata e eterna. E tratam-se de palavras do Führer, quer dizer, de fulgurações não atreladas a algo remotamente semelhante a uma tradição escrita ou afim, mas, antes, que remetem a uma espécie de paródia do "fundamento místico da autoridade" na linhagem de Benjamin e Derrida, com a diferença fundamental em relação à compreensão da questão por esses autores que se constitui na absoluta impossibilidade de interpretação histórica, uma vez que pretende decorrer em momento absoluto, a-histórico, ou fora do tempo, no ponto singular da promulgação de culpa do prisioneiro na Colônia Penal: o momento da própria emissão da ordem pelo Führer. ${ }^{25}$

O resultado cabal de uma tal fixação no absoluto das ordens do Führer, como é de conhecimento histórico geral, foi o exercício contínuo e obsessivo de uma espécie de imperativo categórico kantiano invertido. ${ }^{26}$ A Morte venceu, em todos os sentidos imagináveis dessa expressão. A pulsão de morte achou seu caminho e abriu suas sendas através do que se conhecia como "civilização", deixando heranças das quais as décadas seguintes não têm conseguido se livrar. A idiotia da linguagem é a formalização - ou formulização - da atrofia da vida, quer dizer, um pesadelo de Eros, isso que tão bem caracteriza nazismo e fascismo.

A sintese final de Arendt é magistral, e destaca, ainda uma vez, a questão fundamental da atrofia da imaginação, ou da capacidade imaginativa, como condição para a imersão total no universo fechado da linguagem - e dos atos - que aqui temos chamado idióticos:

24 Ibid., p. 165. Segue Arendt: "A posição de Eichmann, portanto, demonstrava uma semelhança muito desagradável com aquela do muito citado soldado que, agindo dentro de um quadro legal normal, se recusa a executar ordens que contrariam a sua experiência normal de legalidade e que podem ser reconhecidas por ele como criminosas. A extensa literatura sobre o assunto geralmente baseia suas afirmações no sentido comum equívoco da palavra 'lei', que neste contexto significa às vezes a lei local - ou seja, a lei positiva e constituída - e às vezes a lei que supostamente fala ao coração de todos os homens com a mesma voz. Em termos práticos, porém, para serem desobedecidas, as ordens têm de ser 'manifestamente ilegais', e a ilegalidade tem de 'pairar como uma bandeira negra acima [delas] como um aviso de 'Proibido!' - conforme o tribunal indicou. E num regime criminoso essa 'bandeira negra' com seu 'aviso' paira 'manifestamente' acima do que é normalmente uma ordem legal - por exemplo, não matar pessoas inocentes só porque são judeus - da mesma forma como paira sobre uma ordem criminosa em circunstâncias normais. Acreditar numa inequivoca voz da consciência - ou, na linguagem ainda mais vaga dos juristas, num 'sentimento geral de humanidade' (Oppenheim-Lauterpacht em International Law, 1952) - é não só fugir da questão como significa uma recusa deliberada em perceber os fenômenos morais, legais e políticos mais importantes do nosso século." Ibid., p. 165-166.

25 Recorde-se que "O caso de consciência de Adolf Eichmann, que é realmente complicado, mas de modo nenhum único, não é comparável ao caso dos generais alemães, um dos quais, quando the perguntaram em Nuremberg, "Como é possível que todos vocês. honrados generais, tenham continuado a servir um assassino com lealdade tão inquestionável?", respondeu que "não era tarefa de um soldado agir como juiz de seu comandante supremo. Que a história se encarregue disso, ou Deus do céu". (Era o general Alfred Jodl. enforcado em Nuremberg) Eichmann, muito menos inteligente e sem nenhuma formação, percebeu pelo menos vagamente que não era uma ordem, mas a própria lei que os havia transformado a todos em criminosos. Uma ordem diferia da palavra do Führer porque a validade desta última não era limitada no tempo e no espaço - a característica mais notável da primeira. Essa é também a verdadeira razão pela qual a ordem do Führer para a Solução Final foi seguida por uma tempestade de regulamentos e diretivas, todos elaborados por advogados peritos e conselheiros legais, não por meros administradores; essa ordem, ao contrário de ordens comuns, foi tratada como uma lei. Nem é preciso acrescentar que a parafernália legal resultante, longe de ser um mero sintoma do pedantismo ou empenho alemão, serviu muito eficientemente para dar a toda a coisa a sua aparência de legalidade. ARENDT, 1999, p. 166-167.

${ }_{26}$ "E assim como a lei de países civilizados pressupõe que a voz da consciência de todo mundo dita "Não matarás", mesmo que o desejo e os pendores do homem natural sejam às vezes assassinos, assim a lei da terra de Hitler ditava à consciência de todos: "Matarás", embora os organizadores dos massacres soubessem muito bem que o assassinato era contra os desejos e os pendores normais da maioria das pessoas. No Terceiro Reich, o Mal perdera a qualidade pela qual a maior parte das pessoas o reconhecem - a qualidade da tentação. Muitos alemães e muitos nazistas, provavelmente a esmagadora maioria deles, deve ter sido tentada a não matar, a não roubar a não deixar seus vizinhos partirem para a destruição (pois eles sabiam que os judeus estavam sendo transportados para a destruição, é claro, embora muitos possam não ter sabido dos detalhes terriveis), e a não se tornarem cúmplices de todos esses crimes tirando proveito deles. Mas Deus sabe como eles tinham aprendido a resistir à tentação" Ibid., p. 167. 
Eichmann não era nenhum lago, nenhum Macbeth, e nada estaria mais distante de sua mente do que a determinação de Ricardo III de "se provar um vilão". A não ser por sua extraordinária aplicação em obter progressos pessoais, ele não tinha nenhuma motivação. E essa aplicação em si não era de forma alguma criminosa; ele certamente nunca teria matado seu superior para ficar com seu posto. Para falarmos em termos coloquiais, ele simplesmente nunca percebeu o que estava fazendo. Foi precisamente essa falta de imaginação que the permitiu sentar meses a fio na frente do judeu alemão que conduzia o interrogatório da polícia, abrindo seu coração para aquele homem e explicando insistentemente como ele conseguira chegar só à patente de tenente-coronel da SS e que não fora falha sua não ter sido promovido. Em principio ele sabia muito bem do que se tratava, e em sua declaração final à corte, falou da "reavaliação de valores prescrita pelo governo [nazista]". Ele não era burro. Foi pura reflexão - algo de maneira nenhuma idêntico à burrice - que o predispôs a se tornar um dos grandes criminosos desta época. E se isso é "banal" e até engraçado, se nem com a maior boa vontade do mundo se pode extrair qualquer profundidade diabólica ou demoníaca de Eichmann, isso está longe de se chamar lugar-comum. Certamente não é nada comum que um homem, diante da morte e, mais ainda, já no cadafalso, não consiga pensar em nada além do que ouviu em funerais a sua vida inteira, e que essas "palavras elevadas" pudessem toldar inteiramente a realidade de sua própria morte. Essa distância da realidade e esse desapego podem gerar mais devastação do que todos os maus instintos juntos - talvez inerentes ao homem; essa é, de fato a lição que se pode aprender com o julgamento de Jerusalém. (grifo nosso, R. T. S.) ${ }^{27}$

\section{Klemperer e a linguagem totalitária}

"Pensar é uma forma de castração. Por isso, a cultura é suspeita na medida em que é identificada com atitudes criticas". $(E C O, U .)^{28}$
"Ao desejar justificar atos considerados até então como condenáveis, mudar-se-á o sentido ordinário das palavras".

(Tucidides) $^{29}$

"Hitler falava, ou melhor, gritava em convulsões. Até mesmo no máximo da exaltação é possivel manter certa dignidade e algum bem-estar interior, um sentimento de autoconfiança e de estar em harmonia consigo mesmo e com os demais. Esses aspectos faltavam a Hitler, que desde o começo era um retórico consciente, retórico por principio. Não se sentia seguro nem mesmo em uma situação de triunfo, fustigava

com seu linguajar os adversários e as ideias con-

trárias. Não tinha compostura, sua voz não possuía

musicalidade, o ritmo de suas frases açoitava a si mesmo e aos demais. Sua trajetória, pelo menos durante os anos de guerra, transitou de agente provocador a vítima de provocações, de fanático convulsivo a alguém que ia às raias do desespero, demonstrando uma raiva impotente. Nunca fui capaz de compreender como conseguiu conquistar as massas, cativá-las e mantê-las presas sob seu jugo por tanto tempo com

uma voz desafinada e esganiçada, com frases mal construidas na sintaxe alemã, empregando uma retórica claramente contrária ao caráter da lingua alemã".

(V. Klemperer $)^{30}$

É Victor Klemperer quem estabelece, ao longo e logo após a segunda Guerra mundial, uma via de acesso privilegiada às metamorfoses da linguagem promovidas pelo Nazismo como movimento de colonização de corações e mentes..$^{31} \mathrm{O}$ professor e linguista vê-se tomado por uma conjuntura histórica que o obriga a uma situação de escrever - e des-crever - para sobreviver. Seus famosos Diários testemunham essa necessidade vital. São sua herança ao longo da horrenda tempestade do fascismo, do nazismo e da guerra. Escrever, que podia a cada momento significar sua morte, o manteve vivo. Escrever como testemunho, tal como o próprio Klemperer muitas vezes acentuou $^{32}$. Reencontrar a escrita a cada dia, em

\footnotetext{
Ibid., p. 310-311. Sobre o tema da "falta de imaginação, Cf. acima: "Introdução: magia, encantamento, idolatria".

ECO, 2018, p. 48.

TUCIDES Apud FAYE, J.-P., Introdução às linguagens totalitárias teoria e transformação dos relatos, São Paulo: Perspectiva, 2009 , p. 109.

KLEMPERER, V., 2009, p. 106-107.

"In 1968 Hannah Arendt published a study of exemplar lives under the self-explanatory title men in dark times. Victor Klemperer does not figure there, although he would have been a most fitting subject. Arendt did not know, indeed it appears - somewhat strangely - did not even know of. Klemperer. This is to be regretted, for Klemperer must be considered the pioneer of the study of totalitarian language perhaps to this day one of its most insightful analysts. Arendt's 1951 The Origins of Totalitarianism does not mention, but would have been immeasurably enriched by, Klemperer's LTI - Notebook of a Philologist, which had appeared in 1947". ASCHHEIM, S. E., Scholem, Arendt, Klemperer - Intimate Chronicles in Turbulent Times, p. 70. Para uma contextualização cultural geral da obra de Klemperer, Cf. ASCHHEIM S. E. Scholem, Arendt, Klemperer - Intimate Chronicles in Turbulent Times, p. 70-98. Uma excelente introdução à obra de Klemperer se encontra em: SANTOS, M. L., "Victor Klemperer: a linguagem do mal e a nazificação da sociedade alemã", In: Veritas, v. 63. p. 150-189, 2018. 32 A epigrafe geral de Os diários de Viktor Klemperer - testemunho clandestino de um judeu na Alemanha nazista em português, tradução
} 
uma renovação do tempo ainda uma vez, e outra.

Sobrevivente, Klemperer lega à posteridade uma obra notabilissima, que testemunha, na combinação erudita de conhecimento, observação e vivência, o processo de atrofia e idiotização da linguagem alemã ao longo do domínio nazista, acima examinada. Aqui serão destacados alguns excertos dessa obra que contribuem não apenas para a compreensão dos processos de linguagem no âmbito de regimes totalitários mas, também, na era da indústria cultural e suas derivações tardo-capitalistas, que serão examinadas mais adiante na presente obra.

Um primeiro elemento notável que cumpre relevar é a lógica de maquinização do intelecto que se processa através do deslocamento das faculdades cognitivas para as habilidades corporais na nova hierarquia do projeto nazista. O projeto de estatuir a realidade, da somática individual à social, como uma máquina, ou talvez antes como um maquinismo autorreferido semelhante à máquina que imprime a sentença no corpo do condenado em Na colônia penal já está dado no escrito programático do nazismo, e de modo inequívoco. É necessário deslocar a preocupação para a força, o controle físico e o automatismo, o pensar essa função que distingue, pretensamente, os seres humanos dos brutos - é alvo de grande desconfiança; a instalação que pode proporcionar é altamente desconfortável para cada objetivo totalitário. Na mentalidade totalitária, o pensamento é sempre alvo de ataque:

Em Mein Kampf, Hitler, ao tratar de educação, coloca o preparo físico em primeirissimo lugar. Sua expressão predileta é körpeliche Ertüchtigung Icapacitação físical, que ele tomou emprestada do léxico dos conservadores de Weimar. Ele valoriza o Exército do imperador Guilherme como a única organização saudável e vital de um Volkskörper [corpo do povo] apodrecido. Vê no serviço militar, sobretudo ou exclusivamente. uma educação para o desempenho físico. A formação do caráter é uma questão nitidamente menor: dominar o corpo é mais importante do que receber educação. Nesse programa pedagógico, a formação intelectual e seu conteúdo científico ficam por último, sendo admitidos a contragosto, com desconfiança e desprezo. A todo momento se expressa o temor diante do ser pensante e o ódio contra o pensar. Quando Hitler fala de sua própria ascensão, das primeiras grandes manifestações e de seu enorme poder de oratória, ele elogia também a capacidade de combate dos homens que formam sua guarda, aquele pequeno grupo que deu origem às SA. Essas braunen Sturmabteilungen [tropas de assalto marrons] tinham uma função meramente braçal: atacar e enxotar os opositores. ${ }^{33}$

O horror ao pensamento é uma característica fundamental de toda configuração idolátrica. O esforço do pensar é substituido pelo esforço corporal; a perigosa dúvida do que pode ser a realidade propriamente é substituída por algum tipo de culto a algum heroísmo antigo, ou remoto, impalpável, mas reiterado por retóricas renovadas de glorificação esportiva ou sacrificial - "não é o espírito que será vencedor":

Esses são seus cúmplices verdadeiros, ao lado dos quais disputa o coração do povo; são seus primeiros heróis, autênticos exemplos do heroísmo demonstrado nas lutas: mesmo banhados de sangue. são capazes de vencer adversários mais numerosos. Nos relatos de Goebbels sobre a luta por Berlim encontramos as mesmas descrições, a mesma forma de pensar e o mesmo vocabulário. Não é o espirito que será vencedor. Não se trata nem de convencer nem de burilar a retórica da nova doutrina, pois o que conta é o heroismo dos antigos combatentes, "os primeiros homens das SA",34

O que vemos, então, é o deslocamento de uso de uma palavra como kämpferisch - combativo.

de Irene Aron, que cobre os anos de 1933 a 1945, diz poeticamente: "Seguierei escrevendo. Esse é o meu heroísmo. Prestarei testemunho, testemunho preciso." KLEMPERER, V., Os diários de Viktor Klemperer - testemunho clandestino de um judeu na Alemanha nazista, São Paulo: Cia. das Letras, 1999, p. 5

33 KLEMPERER, V., 2009, p. 39-40.

34 Ibid., p. 40. Segue: "Para mim, os relatos de Hitler e de Goebbels se complementam, como observou uma amiga. Naquela época, ela era médica no hospital de Pirna, vilarejo industrial na Saxônia. "Quando, à noite, depois das manifestações, recebiamos os feridos", ela contava amiúde, "eu sabia imediatamente qual o partido de cada um, mesmo se o paciente já estivesse despido no leito: os nazistas eram aqueles que estavam com a cabeça ferida, por suas bebedeiras ou porque tinham brigado usando cadeiras, e os comunistas eram aqueles com os pulmões perfurados por golpes de estilete." Quanto à fama, a história das SA reproduziu a literatura italiana: só se conseguiu alcançar o esplendor nos estágios iniciais; aquele brilho intenso, nunca mais." Ibid., p. 41. 
lutador, beligerante, sempre pronto à disputa - ao centro da referência linguística, substituindo e ampliando o mais corrente kriegrisch - guerreiro -, de escopo mais delimitado e não generalizável. O foco agora é um universo de referência belicoso, e o modus vivendi passa a ser assumir essa belicosidade no dia a dia da sociedade, aderindo as caracteristicas do belicismo àquelas do "heroísmo":

Durante doze anos, o conceito e o vocabulário linguístico do heroísmo estiveram entre os termos prediletos, usados com maior intensidade e seletividade, visando a uma coragem belicista, a uma atitude arrojada de destemor diante de qualquer morte em combate. Não foi em vão que uma das palavras prediletas da linguagem nazista foi o adjetivo kämpferisch [combativo, agressivo, beligerante], que era novo e pouco usado, típico dos estetas neorromânticos. Kriegerisch [querreiro] tinha um significado muito limitado, fazia pensar somente em assuntos de Krieg [guerra]. Era também um adjetivo claro e franco, que denunciava a vontade de brigar, a disposição agressiva e a sede de conquista. Kämpferisch é outra coisa! Reflete de maneira mais generalizada uma atitude de ânimo e de vontade que em qualquer circunstância visa à autoafirmação por meio de defesa e ataque, e não aceita renúncia. $O$ abuso da palavra kämpferisch corresponde ao uso excessivo, errado e impróprio do conceito de heroísmo. 35

Robert Alter relata que, muito embora a língua natal de G. Scholem, o alemão, fosse muito querida por ele, ela havia sido relegada a um plano secundário a partir da sua emigração para a Palestina e que, "ao visitar a Alemanha em 1946, mais de vinte anos depois (da emigração), descobre que nesse meio tempo, [...] a sua lingua natal tinha se transformado em algo feio e estranho"36. "Algo", "something", alguma coisa outra que uma língua normal, algo diferente da forma clássica de transmissão de cultura. A reificação da linguagem, a transformação do mundo linguístico, verbal por sua essência, em uma coisa dominável e explorável é ínsita aos processos de idolatrização da realidade.

Klemperer nos oferece a seguir uma espécie de guia mais esmiuçado do itinerário da língua alemã em direção à sua atrofia e empobrecimento. Entenda-se empobrecimento, aqui, essencialmente como embrutecimento, redução a dimensões rudimentares. O regime sabia do potencial perigo da verdadeira linguagem; por isso, em um primeiro passo, cumpria exercer um controle tão estrito quanto possivel sobre sua formatação e difusão, de acordo com o modus operandi do nazismo como programa político de controle absoluto ${ }^{37}$. O passo seguinte era reduzila a jargões, clichês e gritos, sem distinguir entre a leitura de um texto e a vociferação pregadora de pretensas verdades eternas:

Para ela (a LTI), tudo era discurso, arenga, alocução, invocação, incitamento. O estilo do ministro da Propaganda não distinguia a linguagem do discurso e a linguagem dos textos, razão pela qual era tão fácil declamá-los. Deklamieren [declamar] significa literalmente falar alto sem prestar atenção ao que se diz. Vociferar. O estilo obrigatório para todos era berrar como um agitador berra na multidão., ${ }^{38}$

Nesse ponto, expressa-se uma característica evidente do caráter idolátrico da lógica de domínio da vida do terceiro Reich. Trata-se da redução de

35 Ibid., p. 42-43

36 ALTER, R., Anjos necessários - tradição e modernidade em Kafka, Benjamin e Scholem, Rio de Janeiro: Imago, 1992, p. 89.

37 Ibid., p. 64: "É preciso reconhecer essa riqueza (da linguagem alemã, R. T. S.) - florescente até 1933 e logo em seguida, repentinamente. moribunda - para que se possa perceber a pobreza de espírito dessa escravidão uniformizada, a principal caracteristica da LTI. [...] A razão da pobreza parece evidente. Com um sistema tirânico extremamente invasivo, tudo era vigiado nos minimos detalhes para que a doutrina nacional-socialista permanecesse intacta, sem falsificações em cada um de seus aspectos, incluindo a linguagem. Baseando-se no modelo de censura eclesiástica, os seguintes dizeres constavam na página de rosto dos livros: 'O NSDAP não se opõe à publicação deste texto. Assinado pelo presidente da 'comissão oficial de censura' de proteção ao nacional-socialismo". Ainda: "Só quem fosse membro da Câmara de Letras do Reich tinha permissão para se manifestar. A imprensa só podia publicar o que fosse liberado pelo "órgão central da censura"; no máximo, podia fazer pequenas variações nos textos obrigatórios, da forma mais modesta possivel, variações que se referiam à aparência externa permitida para os clichês." Ibid., p. 64. Segue Klemperer: "Nos anos finais do Terceiro Reich, às sextas-feiras à noite, instituiu-se o hábito de se ler na Rádio de Berlim o artigo mais recente de Goebbels, que seria publicado no Reich do dia seguinte. O conteúdo era liberado para que a imprensa o difundisse em toda a área de influência do nazismo. Assim, um pequeno grupo determinava o modelo linguístico permitido para a coletividade como um todo. Em última instância, Goebbels era o único a definir a linguagem permitida, pois sua vantagem em relação a Hitler era que, além de ter ideias mais claras, também se expressava de forma mais organizada que o Führer, que se calava cada vez mais, como se desejasse manter o silêncio da divindade muda ou porque não lhe restava mais nada decisivo a dizer. Caso houvesse alguma opinião de Göring ou de Rosenberg, o ministro de Propaganda a incluia no texto do próprio discurso." Ibid., p. $64-65$. 38 Ibid., p. 65. 
elementos variados a uma pretensa fonte única de sentido, a um foco de luz que a tudo ofusca e que pretende a tudo cooptar. Não apenas a língua, mas a própria dimensão imagética da realidade se reduz a elementos primários, tão pouco numerosos quanto possivel, imagens que, na verdade, não passam de clichês visuais, e cuja única função é dirigir a atenção à simbólica da dominação da realidade: "Sempre a mesma combinação de força física, intenso fanatismo, musculatura, cenho duro e ausência de sinais de atividade mental"39 - transformação de vida em esculturas e efígies "retratadas" que repetem sempre uma mesma silhueta e que, diferentemente de uma escultura, imagem ou fotografia viva, expressamse através de sua falta de expressão própria "ausência de sinais de atividade mental" - pois sua finalidade não é estabelecerem alguma linguagem possivel com o espectador ou observador, mas, exatamente, desviar sua atenção para além delas, para a simbólica exclusiva da totalidade de sentido promulgada. O momento desse processo de absorção do real por algo - evidentemente, um projeto de Totalidade - que não admite diversidade da realidade ou mesmo algo fora de si é igualmente bem captado por Klemperer, ao descrever como, nesse contexto tratado, a língua autorizada infla sua presença e se coloca, da posição de pars pro toto, em perspectiva de absoluto:

Surge aqui uma nova explicação, bem mais profunda, para a pobreza da LTI.
Ela não era pobre só porque todos se viam forçados a obedecer a um único padrão de linguagem, mas especialmente porque, por meio de uma limitação autoimposta, só permitia expor um lado da natureza humana. [...] A LTI pretende privar cada pessoa da sua individualidade, anestesiando as personalidades, fazendo do individuo peça de um rebanho conduzido em determinada direção, sem vontade e sem ideias próprias, tornando-o um átomo de uma enorme pedra rolante ${ }^{40}$

Veja-se ainda uma vez a característica da "ausência de sinais de atividade mental"; esse dado é fundamental para a compreensão do plano de naturalização idolátrica não só do regime do Terceiro Reich, mas de todo e qualquer sistema totalitário ou totalizante em sentido político, social ou econômico. Trata-se, na verdade, de uma pré-condição a ser atingida para que a naturalização da conjuntura se efetive, ou seja, para que o histórico se transforme em "natural" ou supernatural. Todo sistema de "pensamento" único, toda ideologia de implantação de alguma lógica de violência, controle ou domínio total, em qualquer âmbito da cultura, pretende sempre, já desde o seu início, paralisar o pensamento por algum tipo de enfeixamento energético que conduza as potências da vida a um só foco - o foco da Totalidade ou, no presente caso, o foco idolátrico. Trata-se do que temos chamado de combinação entre um modelo de racionalidade ardilosa e uma expressão de racionalidade

\footnotetext{
39 "Os cartazes nazistas se pareciam uns com os outros. O que se via era sempre o mesmo tipo de guerreiro bruto e adestrado, empunhando uma bandeira, um fuzil ou uma espada, usando uniforme das SA, das SS ou do Exército, ou mesmo com o tronco nu. Sempre a mesma combinação de força fisica, intenso fanatismo, musculatura, cenho duro e ausência de sinais de atividade mental. Eram essas as características da propaganda que lidava com o esporte, a guerra e a subserviência à vontade do Führer." (KLEMPERER, V., 2009, p. 153) $40 \quad$ Ibid., p. 65. (grifo nosso, R. T. S.) Segue Klemperer: "Se puder se expressar com liberdade, qualquer língua consegue dar conta de todos os anseios humanos. Elas se prestam à razão e ao sentimento, são comunicação, diálogo e monólogo, oração e súplica, ordem e invocação. A LTI só se prestava à invocação. O tema podia ser da esfera pública ou privada - não, isso é falso, pois a LTI mal conhecia o domínio privado confundindo-o com a esfera pública, assim como confundia as linguagens escrita e oral -, não importa, tudo era discurso e publicidade. "Tu não és nada, teu povo é tudo", pregava. O que significa que nunca estás sozinho, contigo mesmo, nunca estás a sós com os teus, estás sempre exposto. [...] Seria também enganoso se eu dissesse que, em todos os setores, a LTI dirige-se exclusivamente à vontade. Pois quem apela para a vontade apela sempre para o individuo, mesmo que se dirija a uma coletividade, a um público. [...] A LTI é a linguagem do fanatismo de massas. Dirige-se ao indivíduo - não somente à sua vontade, mas também ao seu pensamento -, é doutrina, ensina os meios de fanatizar e as técnicas de sugestionar as massas." (op. cit., p. 65-66). Sobre a palavra "fanatismo", destaca Klemperer: "Jamais um livro de pregação clerical foi escrito de maneira tão vil e desavergonhada quanto Mein Kampf. de Hitler. Com uma ressalva: em vez de "impostura clerical", a LTI diz 'propaganda'. A maior incógnita do Terceiro Reich, para mim, é entender como esse livro conseguiu penetrar na opinião pública, como permitiu que Hitler dominasse como dominou, e como foi possivel que essa dominação tenha durado doze anos, apesar da biblia do nacional-socialismo ter sido lançada muitos anos antes da tomada do poder. Durante todo o século XVIII francês nunca, jamais, a palavra fanatismo, com seu adjetivo correspondente, ocupou um lugar tão importante, nem foi tão desvirtuada, quanto nos doze anos do Terceiro Reich." (Op. cit., p. 66). Ainda a destacar: "Caracteristica inconteste da LTI é a flagrante mecanização da própria pessoa. Nesse campo, a criação mais clara e provavelmente a mais precoce é o verbo gleichschalten Isincronização da voltagem na energia elétrica, uniformização de ideias, atitudes e ações, especialmente no que diz respeito a acertar o passo nas paradas militares]. Pode-se ver e ouvir o clique do botão que faz pessoas - não instituições nem administrações despersonalizadas - adotarem posições e movimentos uniformes e automáticos: professores de diversas instituições, funcionários de serviços jurídicos ou administrativos, membros dos Stahlhelm Icapacetes de aço] ou das SA etc. etc. sempre são conduzidos gleichgeschaltet lem sintonia], de maneira coordenada". (Op. cit., p. 245).
} 
vulgar $^{41}$, que acaba resultando na racionalidade idolátrica. Ocorre uma aparência de pensamento já pensado, que interdita o questionamento e, por óbvio, a consideração realista do que realmente se passa. Não é nenhum acaso que todo modelo totalizante de sociedade ataque imediatamente a tradição cultural das línguas, da história, da geografia e, especialmente, da filosofia - ou seja de tudo que pode deslocar suficientemente o estatuido para expor, pela radicalização - pelo ir às raizes - onde verdadeiramente assentam os alicerces do projeto totalitário/totalizante e de seus aparatos de legitimação. Por evidente. isso ocorreu de forma modelar no Terceiro Reich:

Quem pensa não quer ser persuadido, mas sim convencido; é bem mais difícil convencer quem está habituado a pensar sistematicamente. Por isso a LTI detesta a palavra filosofia, mais ainda do que a palavra sistema. A LTI dá uma conotação nociva ao termo "sistema": mas o emprega com frequência; não pronuncia jamais a palavra filosofia, sempre substituida por Weltanschauung [visão de mundo]. ${ }^{42}$

Uma ideologia se configura quando um modelo de pensamento ou um projeto filosófico é detido em meio a seu desenvolvimento com o objetivo de legitimar alguma causa, tornando-se autorreferente, idiota; nesse sentido, como em tantos outros, o Nazismo foi uma ideologia perfeita que se consubstanciou de forma espetacular durante seu periodo de vigência pela habilidade com que seus arquitetos souberam conduzir uma quantidade de variáveis que obliterou a consciência de algo mais profundo do que ele mesmo por parte daqueles não diretamente atingidos por suas lógicas de violência - grupo no qual se inclui uma boa parte dos alemães de então, e da imensa maioria dos estrangeiros. E é de se notar que se constitui em tarefa desmesurada ou impossivel distinguir entre os alheios aqueles que realmente ignoravam o que ocorria e aqueles a quem a ignorância funcionou como estilo de convivência hipócrita e, em certos casos, mesmo como estratégia de sobrevivência no calor dos acontecimentos; essa indistinção é caracteristica de épocas psiquicamente perturbadas de uma determinada cultura, na qual a paranoia se instala como elemento ambíguo que assume a dupla tarefa de amplificador de medos reais e propagador de angústias difusas a serviço da instilação de dimensões paralisantes nas lógicas elementares da vida43. "Não pronuncia jamais a palavra filosofia".

Essas são condições prévias de ativação de elementos inconscientes e subconscientes (e aqui destacamos o embrutecimento da linguagem, ou sua crescente ausência daquilo que, socialmente, se apresenta como sendo ela) que irão permitir a idolatrização de alguma figura que pretende se constituir, ou encarnar, a totalidade de sentido. Tivemos, assim, no Terceiro Império, a configuração de uma idolatria particular, aquela de Hitler mesmo. O que pode soar extravagante e insano a uma leitura epocalmente deslocada testemunha exatamente a que ponto um tal aparato mental pode se instalar em uma multidão de dimensões dificilmente apreciáveis e em todas as suas expressões vitais, e mesmo entre alguns dos melhores entre elas, gente refinada, da qual não se esperaria a precipitação em tal abismo de delírio:

(...) Mas o Führer não pode nem deve falar todos os dias. A divindade tem de ocupar um trono sobre as nuvens, e seus pronunciamentos devem ser feitos mais pela boca dos sacerdotes do que pela própria. No caso de Hitler, essa é uma vantagem adicional, pois seus amigos e servidores podem erigi-lo em salvador de maneira ainda mais firme e com maior desenvoltu$\mathrm{ra}$, venerando-o ininterruptamente e em coro. De 1933 a 1945, até mesmo depois da queda de Berlim, dia após dia houve essa elevação do Führer à categoria divina, essa identificação de sua pessoa e suas ações com o salvador e com a Biblia, e "tudo funcionou sempre às mil maravilhas". Sob a prepotência reinante. ninguém pôde contradizê-lo jamais. (...) Citarei alguns exemplos dos casos absurdos de endeusamento. Emjulho de 1934. Göring diz diante da Câmara Municipal de Berlim: Wir alle, vom einfachsten SAMann bis zum Ministerpräsidenten, sind von Hitler und durch Hitler [Todos nós,

${ }_{41}$ Cf. SOUZA, R. T., Ética do escrever - Kafka, Derrida e a Literatura como crítica da violência, Porto Alegre: Zouk, 2018, p. 43-54.

42 KLEMPERER, V., 2009, p. 177.

43 Cf. FREUD, S., Psicologia das massas e análise do eu. Porto Alegre: L\&PM, 2019; ADORNO, T. W., Ensaios sobre psicologia social e psicanálise, São Paulo: UNESP, 2015, entre outros. 
desde o mais simples membro das SA até o primeiro ministro, somos de Adolf Hitler e por Adolf Hitler]. (...) Baldur von Schirach transforma Braunau, cidade natal de Hitler, em local de peregrinação da juventude alemã. Publica também Das Lied der Getreuen [Cântico dos fiéis], "versos da juventude hitlerista austriaca anônima durante os anos da perseguição de 1933 a 1937, em que consta: Es gibt so viele, die dir nie begegnen und denen trotzdem du der Heiland bist [Tanta gente que nunca te viu, mas sempre te amou, nosso divino salvador, nós austriacos perseguidos]. (...) Nessa altura, todos invocavam a Providência, não somente aqueles que pela origem social e a formação pudessem ser considerados mais sugestionáveis e que facilmente ficariam deslumbrados. Também Kowalewski, o magnifico reitor da Universidade Técnica de Dresden, conceituado professor de matemática, escreveu: Er ist uns von der Vorsehung gesandt [Foi-nos enviado pela Divina Providência]. Pouco antes do ataque à Rússia, Goebbels retorna com mais força ao tema do endeusamento. No discurso de votos de felicidades para o 20 de abril de 1941, ele diz: Wir brauchen nicht zu wissen, was der Führer will - will glauben an ihn INão precisamos saber que o Führer deseja - acreditamos nele]. ${ }^{44}$

Victor Klemperer, testemunha privilegiada dos acontecimentos, sobreviveu à loucura, como seu famoso primo refugiado, Otto Klemperer, grande maestro. Mas a loucura está sempre ante portas; quem olvida tal fato terá muito provavelmente de prestar, em algum momento, contas à história.

\section{Considerações finais - atualidade das análises e Arendt e Klemperer e lógicas de "pós-verdade"}

Arendt e Klemperer, testemunhas privilegiadas de tempos obscuros, realizam, cada um a seu modo, hermenêuticas das linguagens totalitárias que de modo algum permanecem prisioneiras de suas épocas ou circunstâncias. Pelo contrário, suas análises assumem recentemente uma inaudita atualidade. Quando "pós-verdade" foi apontado como "termo do ano" em 2017, muitos intelectuais se obrigaram a examinar esse estranho termo em busca de suas raízes racionais - ou irracionais. As análises de Arendt e Klemperer nos fornecem chaves preciosas para compreender as lógicas de discurso que permitiram a sustentação de tais narrativas "pós-verdadeiras" ao redor do mundo. Nihil sub sole novum: o fascismo e o nazismo forneceram, ao longo do tempo e em diversas línguas, verdadeiros "manuais" de manipulação e transformação da linguagem em função de seus objetivos. Tal como o fascismo, no dizer de Umberto Eco, tem uma dimensão eterna, igualmente possui uma dimensão eterna a invectiva de manipular individuos através da linguagem, e isso até um nível inaudito - como bem o prova o status dos discursos de "pósverdade" assumidos como certezas por uma civilização global regressiva e adoentada. E essa situação se constitui, definitivamente, uma questão filosófica de primeira linha nos dias que correm.

\section{Referências}

ADORNO, T. W. Ensaios sobre psicologia social e psicanálise. São Paulo: UNESP, 2015.

ARENDT, H. Eichmann em Jerusalém: um relato sobre a banalidade do mal São Paulo: Cia. das Letras, 1999.

ASCHHEIM, S. E. Scholem, Arendt, Klemperer: Intimate Chronicles in Turbulent Times. Bloomington: Indiana University Press, 2001

ALTER, R. Anjos necessários: tradição e modernidade em Kafka, Benjamin e Scholem. Rio de Janeiro: Imago, 1992.

ECO, U. O fascismo eterno. Rio de Janeiro: Record, 2018.

FAYE, J. P. Introdução às linguagens totalitárias teoria e transformação dos relatos. São Paulo: Perspectiva, 2009 .

FREUD, S. Psicologia das massas e análise do eu. Porto Alegre: L\&PM, 2019.

HORKHEIMER, M. Eclipse da razão. São Paulo: Centauro, 2002

KAFKA, F. O Veredicto/Na Colônia Penal. São Paulo: Companhia das Letras, 1998.

KLEMPERER, V. LTI: A linguagem do terceiro Reich. Rio de Janeiro: Contraponto, 2009.

KLEMPERER, V. Os diários de Viktor Klemperer: testemunho clandestino de um judeu na Alemanha nazista. São Paulo: Companhia das Letras, 1999.

SANTOS, M. L. Victor Klemperer: a linguagem do mal e a nazificação da sociedade alemã. Veritas, Porto Alegre, v. 63, n. 1, p. 150-189, 2018. https://doi. org/10.15448/10.15448/1984-6746.2018.1.29499. 
SOUZA, R. T. Kafka, a justiça, o Veredicto e a Colônia Penal. São Paulo: Perspectiva, 2012.

SOUZA, R. T., Ética do escrever: Kafka, Derrida e a Literatura como crítica da violência. Porto Alegre: Zouk, 2018.

\section{Ricardo Timm de Souza}

Doutor em Filosofia - Albert-Ludwigs-Universitaet, Freiburg - (Alemanha). Professor Titular da Pontificia Universidade Católica do Rio Grande do Sul (PUCRS, Porto Alegre, RS, Brasil) na Escola de Humanidades, professor no PPG Filosofia e no PPG Letras da mesma instituição.

\section{Endereço para correspondência}

Ricardo Timm de Souza

Pontifícia Universidade Católica do Rio Grande do Sul Av. Ipiranga, 6.681, Prédio 8, $4^{\circ}$ andar

Partenon, 97010-082

Porto Alegre, RS, Brasil 